\title{
Preadvanced Japanese
}

JPN 399 


\title{
Preadvanced Japanese
}

\author{
By Emiko Konomi
}


(C) 2018 Emiko Konomi

Originally published in 2014

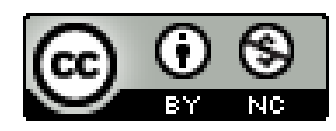

This work is licensed under a Creative Commons Attribution-NonCommercial 4.0 International License You are free to:

- Share - copy and redistribute the material in any medium or format

- Adapt - remix, transform, and build upon the material

The licensor cannot revoke these freedoms as long as you follow the license terms.

Under the following terms:

- Attribution - You must give appropriate credit, provide a link to the license, and indicate if changes were made. You may do so in any reasonable manner, but not in any way that suggests the licensor endorses you or your use.

- NonCommercial - You may not use the material for commercial purposes.

This publication was made possible by PDXOpen publishing initiative

Published by Portland State University Library

Portland, OR 97207-1151

Cover design by Matt Eich 


\section{About the Book}

This textbook is designed for beginning learners who want to learn basic Japanese for the purpose of living and working in Japan. Unlike textbooks written primarily for students, whose content largely centers on student life, this book focuses more on social and professional life beyond school.

This textbook can be used for self-study, as part of an online course, or as a traditional college course. As a beginning level textbook, this book includes many elementary grammar patterns (Japanese Language Proficiency Test Levels 5 and 4), but the vocabulary and situations are selected specifically for working adults. Explanations are kept concise so as to only cover key points. The main focus is on oral communication.

\section{About the Author}

Emiko Konomi received a PhD in Linguistics from Cornell University and has been on the faculty of the School of Business Administration at Portland state University since 2014. Prior to joining SBA, Emiko taught in the Department of World Languages and Literatures at PSU. She also has extensive experience training Japanese language instructors at various teacher-training programs across the country. Currently Emiko teaches all levels of Japanese to students in the Masters of International Management program.

Known for her passionate teaching style and dedication to quality teaching, Emiko received the 2011 and 2015 John Eliot Allen Outstanding Teaching Awards from the College of Liberal Arts and Sciences. Her academic research focuses on Japanese linguistics and pedagogy.

\section{Acknowledgments}

Many thanks to the reviewers:

Dr. Kasumi Yamamoto

Chair and professor of Japanese

Williams College

Yoshimi Nagaya

Director of Japanese Language

Massachusetts Institute of Technology 


\section{Before We Start}

\section{Q: What level does this textbook target?}

This textbook is designed for students who have intermediate competency in Japanese, roughly at Level 2 on the ILR (The Interagency Language Roundtable) proficiency scale, and are working on reaching Level 3.

\section{ILR Level 2 - Limited working proficiency}

- able to satisfy routine social demands and limited work requirements

- can handle with confidence most basic social situations including introductions and casual conversations about current events, work, family, and autobiographical information

- can handle limited work requirements, needing help in handling any complications or difficulties; can get the gist of most conversations on nontechnical subjects (i.e. topics which require no specialized knowledge), and has a speaking vocabulary sufficient to respond simply with some circumlocutions

- has an accent which, though often quite faulty, is intelligible

- can usually handle elementary constructions quite accurately but does not have thorough or confident control of the grammar.

\section{ILR Level 3 - Professional working proficiency}

- able to speak the language with sufficient structural accuracy and vocabulary to participate effectively in most conversations on practical, social, and professional topics

- can discuss particular interests and special fields of competence with reasonable ease

- has comprehension which is quite complete for a normal rate of speech

- has a general vocabulary which is broad enough that he or she rarely has to grope for a word

- has an accent which may be obviously foreign; has a good control of grammar; and whose errors virtually never interfere with understanding and rarely disturb the native speaker.

\section{Q: How should this textbook be used?}

This textbook can be used for self-study, as part of online course, and in a traditional classroom setting. It is comprised of three chapters, intended to be covered in one term of a quarter system. 
Each chapter starts with 本文, the Main Text, introducing the theme of the chapter and presents みんなの声, Our Opinions, expanding on the theme. Students can copy and paste the entire text to one of the various online reading/annotation tools such as the following:

http://dokkai.mit.edu/reading_student.cgi

http://www.polarcloud.com/rikaichan/

http://translate.weblio.jp/

These are useful tools. It's important to become proficient using them, for they will be most likely part of our lifelong learning of Japanese.

\section{Q: How do we learn vocabulary?}

表現ノート, Notes on Expressions, provide information on selected expressions and grammar, but you will not find vocabulary lists in this textbook. This is because one list does not serve everyone. The online reading sites listed above allow students to create their own custom vocabulary lists with one click. The availability of these online tools free students from the need to flip through paper dictionaries or to enter each item in digital dictionaries. The time saved can be used to strengthen reading comprehension skills.

Repetition is key to improving memory. This textbook is structured to ensure ample repetitions of key words and expressions in both the texts and the audio.

\section{Q: How do we practice speaking and listening?}

Functional reading requires simultaneous processing of multiple elements of language. Therefore, it's critical that training in reading skills utilizes audio, which learners listen to and repeat. If you are not already familiar with the sound, meaning, and conversational use of the words and expressions used in the text, it's likely that you are decoding rather than reading. Ideally, sub-vocalization should happen when reading both foreign and native language texts. Sub-vocalization helps with linguistic processing. The audio will support your learning how to vocalize, which is the prerequisite for appropriate sub vocalization.

In addition, as students participate in class discussions and other activities related to their reading, vocalization skills will be reinforced, along with speaking and listening.

Remember that in our everyday life, reading is usually not an end in itself. After we read, we engage in various activities: tell others about what we read, share our opinions and debate the issues, make presentations, etc. All these activities require that you be able to TALK about what you read.

Each chapter has Drills on expressions and grammar, Kanji Drills, and Listening Exercises. These activities are to be performed using the accompanying audio. The 
symbol indicates that there is an audio file for that section. The Main Texts, Our Opinions, and all the Drills have audio files.

In addition, each chapter contains video files of natural and unscripted interviews with native speakers on the theme. Viewing these videos, students can observe facial expressions, gestures, mannerisms, tone of voice, shifts in speech styles, dialects, and other communicative and cultural elements that are not typically presented in a textbook.

\section{Q: How do we learn Kanji?}

When we read, we recognize words and phrases and their readings, rather than individual symbols. We process the sounds and comprehend the meaning. When we encounter an unrecognized written word, we try to "sound out" and guess its meaning and reading. If we focus on individual Kanji and their meaning in English, this may hinder leaning how to read.

For this reason, we need to learn Kanji using meaningful words and phrases, their readings, and their English meanings, instead of focusing on the original meaning of individual kanji character in isolation. This is also critical in developing your scanning skills, which is essential for functional reading.

You can make your own custom kanji /vocabulary lists using the online reading tools as mentioned above. In this textbook, major kanji words and expressions from the main texts are listed in Kanji Drills. The accompanying audio provides their correct readings. There are pauses before and after the model reading. The recommended procedure for these drills is to first try sounding out each word and test your memory during the first pause, check the model reading with the audio, and then repeat the model yourself during the second pause. Make sure you speak aloud.

Once you become comfortable reading the words, you are then ready to start writing. This follows the pedagogical principle that a passive activity should precede a productive activity. Production is easier when you have already established a solid visual memory.

To learn kanji stroke order, there are many excellent sites on the Internet. Find one that works for you.

\section{Q: What other activities can supplement this textbook?}

Upon completing each chapter in the textbook, students are ready to engage in more expanded linguistic activities and assignments utilizing what they have learned. These activities include team debates, PowerPoint presentations, speeches, interviews, videoconferences, emailing/texting, essay writing, online research, translations, blogs and online review writing.

Suggested topics for these activities are listed at the end of each chapter as まとめ, Summary. 


\section{レッスン 1：自己紹介}

It may not be common to touch on all the topics below in a self-introduction, but these are commonly asked items that pop up in any personal conversation. It's helpful to prepare a solid script, both a formal and informal version, which you can fall back on at any time. Style, order, and topics to include should be chosen as appropriate for the particular situation.

1. Opening remarks. You name, affiliations, and status.

2. Reasons why you are here

3. Birthplace, home, current residence

4. Educational background (elementary through college)

5. Work history

6. Family and childhood

7. Personality (what you think of yourself and how others describe you)

8. Hobbies and interests

9. Favorite words, blood type, zodiac sign

10. Future plans, dreams and aspirations

11. Closing

\section{\&本文}

初めまして。デビー・スミスと申します。ポートランド州立大学 の三年生で、専攻は国際学です。今年の九月から留学生として、早 稲田大学国際学部で勉強しています。来年の春までこちらにいる予 定です。今は、大学の寮に住んでいます。

出身はアメリカのオレゴン州のポートランドです。ポートランド はシアトルから車で三時間ぐらいのきれいな町で、人口約 60 万人、 アメリカで最も住みやすい町の一つと言われています。日本人も多 いようです。私は小学校から高校までポートランドの公立学校に行 き、それからポートランド州立大学に入学しました。日本語は高校 で一年、大学で三年ほど勉強しました。まだまだ下手ですが、一生 懸命がんばっています。 
Created by Emiko Konomi 2014

家族は四人で、両親と高校三年生の妹がいます。祖父母や親戚が カリフォルニアにいるので、夏休みなどによく遊びに行きます。子 どもの時は妹とよくけんかしましたが、今は仲がよくて、お互いに、 いい相談相手になっています。おたしは、性格はどちらかというと 明るくてさっぱりしている方です。小さい事はあまり気にしません。 友だちからも、おおらかというか、のんきだとよく言われます。

趣味は読書で、特に日本文学が好きです。好きな作家は三島です。 それから今、ヨガに凝っています。友だちに誘われて始めたんです が、すっかりはまってしまって、今ではヨガオタクと呼ばれていま す。それから旅行も好きで、旅行中に撮った写真をブログに載せた りしています。

まだ就職した経験はありませんが、高校生のときから色々なアル バイトをしてきました。事務員、店員、ウェートレス、家庭教師な どです。将来は、IT 関係の企業に就職して、グローバルな仕事がし たいと思っています。

ちなみに、誕生日は二月二十日の魚座です。血液型は 0 型です。 尊敬する人はスティーブ・ジョブス、好きな食べ物はイタリアン、 好きな言葉は七転び八起きですかね。ついでに、ただいま恋人募集 中です。では、よろしくお願いいたします。

\section{表現ノート}

1. 約 approximately

約 precedes a quantity expression

(counting classifiers; not naming classifiers) 
Created by Emiko Konomi 2014

\section{2. 最も most, best}

人口約六十万人 population approximately 60,000

約一週間 approximately one week

最も is more formal than一番

アメリカで最も住みやすい町の一つ

one of the best places to live in America

3. 一生懸命 hard, as hard as one can

テストがあるので、一生懸命勉強している。

I'm studying as hard as I can because I have a test.

一生懸命頼んだが，聞いてもらえなかった。

I begged him wholeheartedly but he didn't listen.

4. 相手和 the other party, partner, opponent

相談相手 person to confide in, adviser, counselor

結婚相手ｍarriage partner, spouse

相手のチーム opposing sports team

5. どちらかというと if I have to choose one way or another/ rather / if anything

どちらかというと和食より洋食の方がいいですけど

I'd prefer western food to Japanese food if I have to pick one.

スポーツはどちらかというと苦手です。

I'm rather bad at sports.

6. Xというか rather than X, it's more like.../not exactly X but rather....

というか can also occur by itself in a casual speech, indicating that you are looking for a better expression.

おおらかというか、のんきだ。

She is easygoing...or rather, nonchalant.

7. さっぱりしている light/frank/not worrying / not holding a grudge

さっぱりした食べ物 light food, refreshing and not greasy food

お風呂に入ってさっぱりした

Having taken a bath, Ifeel refreshed.

8. X に凝る get really into $X /$ become fanatic about $X$

ヨガに凝っている I'm into Yoga.

凝った名前 elaborate names

9. X ははまる fit in X, get hooked on X (colloquial)

ここのラーメン、一度食べるとはまっちやいますよ。

If you eat the ramen here once, you'll be hooked.

10. オタク fanatic/geek/nerd/freak

ヨガオタク Yoga fanatic

健康オタク health fanatic 
Created by Emiko Konomi 2014

11.ブログに載せる post it on the blog (Transitive)

載る get published, get posted, appear (Intransitive)

新聞に載っている It's in the newspaper.

12. ちなみに by the way /just so you know (this may be off topic, but....)

13. ついでに incidentally /on the way to do $X /$ while you do $X$

コンビニに行くなら、ついでにパン買ってきて。

If you are going to a convenience store, get me some bread as well.

日本に行くついでに、中国にも行く。

I'm going to Japan anyway, so I'm going to China as well.

14. 七転び八起き

15. 募集中
If you fall seven times, get up eight.

recruiting, now taking applications

ウェートレス募集中 waitress wanted

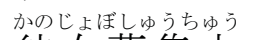

彼女募集中 seeking a girlfriend

読解チェツク

Answer the following questions in Japanese ORALLY. These questions are recorded on the audio. Do not look at the script as you listen to the audio. The script is here to help you only when you cannot comprehend the questions by listening alone.

1.この自己紹介はだれに向かってしていると思いますか。どうして そう思いますか。

2. スミスさんは何歳ぐらいの人でしょうか。どうしてそう思います か。

3.どうして日本語がこんなにできるんですか。

4. どうして日本に来たのですか。

5.出身は、どちらですか。そこは、どんな町ですか。

6.スミスさんはどの大学を卒業しましたか。それは私立大学ですか。

7. 大学の専攻は、日本文学ですか。

8.スミスさんのご家族はどちらにいらっしゃいますか。

9. 何人兄弟ですか。 
Created by Emiko Konomi 2014

10. 仲がいいですか。

11. スミスさんとカリフォルニアの関係は?

12. スミスさんは自分はじんな性格だと思っていますか。お友だち はどう思っていますか。

13. 今一番気に入っている趣味は、何でしょうか。

14. どうして、オタクと呼ばれているのですか。

15. 三島というのはだれですか。スティーブ・ジョブスは?

16. スミスさんは今までにどんな仕事をしてきましたか。

17. それを将来も続けるつもりですか。

18.この人はどんな料理が好きですか。

19. 好きなことわざは何ですか。それはどういう意味ですか。

20. 日本でよく聞かれる質問で、アメリカではほとんど聞かれな いのは、どんな質問ですか。

\section{\&ドリル}

Listen to the audio. Respond to each cue, following the first two model exchanges.

A. 人口は、一万人ぐらいですか. 旅行は、一週間ぐらいですか。 人口ですか。はい、約一万人だそうです。 旅行ですか。はい、約一週間だそうです。

1.このアルバイトは一ヶ月ぐらいですか。

2. 留学は百万円ぐらいですか。

3. 国際学専攻の学生は、百人ぐらいですか。

4. シアトルからポートランドまで三時間ぐらいですか。

5. 日本文学のレポートは十ページぐらいですか。

B.この町、住みやすいですねえ。

ええ、最も住みやすい町の一つだと言われています。 
この相手、強いですねえ。

ええ、最も強い相手の一人だと言われています。

1.このレストラン、予約がとれませんねえ。

2. この作家、売れています视え。

3.このサッカーチーム、ファンが多いですねえ。

4. このブログ、人気がありますねえ。

5.この人、若者に尊敬されていますね视。

C. 性格、明るいですか。

この町、住みやすいですか。

まあ、どちらかというと、明るい方ですかねえ。

まあ、どちらかというと、住みやすい方ですかねえ。

1. 兄弟は、仲がいいですか。

2. 留学生、多くなりましたか。

3. この授業, 勉強になりますか。

4. 恋人、欲しいですか。

5. 血液型、気にしませんか。

D. 彼女、下手ですよ㸚え。

というか、まあ、あまり上手じやないのはたしかですね。 ここ、住みにくいですよねえ。 というか、まあ、あまり住みやすくないのはたしかですね。

1. 仲が悪いですよねえ。

2. 性格、暗いですよ亦え。

3. シアトル、遠いですよ斌え。

4. 経験、少ないですよねえ。

5. 就職、むずかしいですよねえ。

E. 趣味は、写真ですか。省、今写真に凝っています。 趣味は、ブログですか。 ええ、今ブログに凝っています。

1. 趣味は、料理ですか。

2. 趣味は、読書ですか。

3. 趣味は、車ですか。

4. 趣味は、旅行ですか。

5. 趣味は、ランニングですか。

F. あの写真、ブログに載せますけど。

じゃ、ついでにこの写真も載せてください。 
Created by Emiko Konomi 2014

あのこと、相談しますけど。

$$
\text { じゃ、ついでにこのことも相談してください。 }
$$

1.あのアルバイト、募集しますけど。

2. あのアパート、紹介しますけど。

3. あの企業、調べますけど。

4. あの家庭教師の予定、聞きますけど。

5. あの留学生の専攻、書いてもらいますけど。

Listen to the audio. Indicate whether or not each statement is in line with the main text by marking O (マル: Correct) or X (バツ Incorrect or Undeterminable). Explain in English why you marked an item incorrect or undeterminable.
1.
2.
3.
4.
5.
6.
7.
8.
9. 10.

\section{漢字ドリル}

Listen to the audio for the correct reading of each kanji. Try reading the Kanji yourself during the first pause, listening to the correct reading, and then repeating after the model during the second pause.

1. 専攻 major subject / college major

2. 国際学 international studies

3. 留学生 foreign exchange student / overseas student

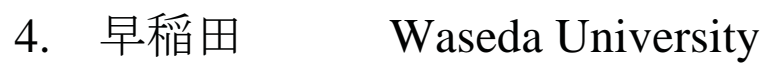

5. 予定 plans / schedule / program

6. 寮 dormitory

7. 出身 person's home town

8. 最も most / extremely

9. 公立学校 public school 
Created by Emiko Konomi 2014

10. 一生懸命 trying very hard / with all one's might

11. 祖父母 grandparents

12. 親戚 relative

13. 仲がいい good relationship / get along well

14. お互い mutual / reciprocal

15. 相談相手 adviser / confidant

16. 性格等 character/personality

17。明るい bright / cheerful

18. 趣味 hobby / tastes / preference

19. 読書 reading

20. 特に especially / particularly

21. 日本文学 Japanese literature

22. 作家 author / writer / novelist

23. 三島 family surname

24. 撮る take (a photo) / make (a film)

25. 写真 photograph

26. 載せる place (on something) / load

27. 就職年 finding employment

28. 経験 experience

29. 事務員ｃlerk

30. 店員 store employee / salesperson

31. 家庭教師 tutor

32. 将来 future (usually near) / prospects 
Created by Emiko Konomi 2014

33. 企業 enterprise / corporation

34. 誕生日 birthday

35. 魚座 Pisces (constellation)

36. 血液 blood

37. 血液型 blood type

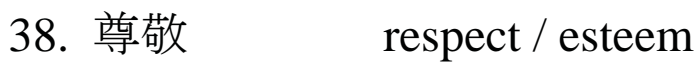

39. 転ぶ fall down / fall over

40. 七転び八起き ups and downs in life / always rising after a fall

41. 恋人 sweetheart

42. 募集 recruiting / taking applications

\section{•みんなの一言}

$\mathrm{A} さ ん$

私は、社交的な方だと思います。一人でいるよりだれかと一緒に いる方が好きだし、だれとでもでもうまくやって行く自信がありま す。でも八方美人じゃないですから。

$$
\mathrm{B} さ ん
$$

私は子どものとき、すごい恥ずかしがり屋で、よく人見知りをし ました。おとなしい子で、友だちも少なかったし、いつもペットの 犬と遊んでいました。信じられないでしょう。

$$
\text { Cさん }
$$


Created by Emiko Konomi 2014

最近の若い人は、わがままというか、無責任で自分さえ良ければ いいという自己中な人が多いねえ。もっと大人になれって言いたい よ。

$$
\mathrm{D} さ ん
$$

やはり人気があるのは、ノリが良くて、テンションの高い人。も てるのは、女性ならかわいい人、男性ならイケメンかな。だから、 ぼくはだめ。全然だめ。

$$
\mathrm{E} さ ん
$$

どんなに仕事ができても、空気が読めない人は、きらわれますよ。 反対に、気が利く人はみんなに好かれるよね。

$$
\mathrm{F} さ ん
$$

父は気が短くてすぐ怒るタイプだし、母は心配性でいつも心配ば かりしています。私はどちらにもなりたくないと思っていたのに、 やっぱり似ちやいました。親子ですから、仕方ないですね。

$$
\mathrm{G} さ ん
$$

ユーモアのセンスがある人は一緒にいて楽しいけど、真面目すぎ て圥談が通じない人は、付き合いにくい。もちろん、だらしない人 はいやだけど、几帳面過ぎるのも、肩が凝るっていうか......

$\mathrm{H}$ さん

うちの子は、親に似て勉強はできないだろうけど、素直で思いや りのある子に育ってくれたら、それで、充分です。 Iさん 
Created by Emiko Konomi 2014

私が尊敬するのは、冷静で、頭が良くて、前向きな人です。人の 気持ちが分かる人。あきらめない人。そして、なにより謙虚な人で す。

\section{Jさん}

考え方が広くて自由な人は、おもしろいアイデアを出すし、古い 考え方に縛られている人は、そのアイデアをつぶしてしまう。あな たはどちら?

$$
\text { みんなの一言 表現ノート }
$$

1. 先等美人 person who tries to please everybody, universal flirt

2. 拀ずかしがり屋 shy person

Adjective Root (Adj. withoutい)+がる

屋 person who specializes in $X$, who is characterized by $X$

さび

菽しがり屋 person who gets lonely easily

気分屋 moody person

3. 人筧知り、人見知りをする shy around strangers

4. うまくやって行く get along well with peoplelon the job

うまくやって下さい。 Get along with people. Handle it well.

仕事がうまく行った The work went well.

5. 自己中 (col. = colloquial) 自己中心的（な）

egotistic, selfish / self-centered

6. ノリがいい (col.) person who is witty/fun and exciting

7. テンションが高い (col.) energetic, hyped, excited

テンションが上がる exciting / get excited/get psyched up

8. イケメン (col.) cool or good-looking man

9. 空気を読む : sense what is going on in the situation

空気が読めない unable to sense what is going on

10. Xに似る be resemble or look like X

父に似ている resembles my father

似た漢字 similar kanji 
Created by Emiko Konomi 2014

11. 觉談が通じないdo not understand jokes / can't take jokes

Xが通じる X is understood

英語が通じる English is understood.

ことば

言葉が通じない do not understand (someone)

話が通じない do not understand a topic / story

12. X過ぎる overly $X$

Verb Stem/Adj. Root/な noun + 過ぎる

几帳面過ぎる、細か過ぎる too meticulous / anal-retentive

13. 肩が凝る get stiff shoulders / too serious / too formal / can't relax

肩が凝る話 talk that is too serious and formal

一緒にいて肩が凝らない人 person I can be relaxed around

14. X に縛られる tied to $X /$ restricted by $X$

縛る : tie / bind

仕事に縛られて、等由な時間がない

性格に煵する表埇現

I'm tied up with my work and have no free time.

15. 暗い

16. 岕配性

dark/ gloomy / depressed

しゃこうてき

17. 社交的（な）

prone to worrying

18.わがまま（な）

sociable

19. 無責任（な）

selfish

20. 気が利く

irresponsible

21. 気が短い、短気 (な) short tempered

22. だらしない

slovenly / untidy / undisciplined

23. 几帳面 (な)

methodical / punctual / steady

24. 思いやりがある

have consideration / sympathy

25. 泠静 (な)

calm / composed

26. 前向き（な）

27. 謙虚（な）

front-facing / forward-looking / positive

modest / humble

$$
\text { \&インタビュー }
$$

Interview a Japanese person and fill out the form below. 
Created by Emiko Konomi 2014

$$
\text { インタビュー報告書 }
$$

\begin{tabular}{|c|c|c|}
\hline 1. & 氏名 & \\
\hline 2. & 住所 & \\
\hline 3. & $\begin{array}{l}\text { 年齢 } \quad \text { 才 } \\
\text { 生年月日＼cjkstart昭和／平成 }\end{array}$ & 月 \\
\hline 4. & 職業 & \\
\hline 5. & $\begin{aligned} \text { 学歴 : 小学校 } \\
\text { 中学校 } \\
\text { 高校 } \\
\text { 大学 }\end{aligned}$ & $\begin{array}{r}\text { 卒業 } \\
\text { 卒業 } \\
\text { 卒業 } \\
\text { 卒業 } / \text { 在学 }\end{array}$ \\
\hline 6. & 専攻 & \\
\hline 7. & 職歴 & \\
\hline 8. & 特技／資格 & \\
\hline 9. & 家族 & \\
\hline 10. & 趣味 & \\
\hline 11. & 性格 & \\
\hline 12. & 血液型 $\quad \mathrm{A}$ 型 $\mathrm{B}$ 型 $\mathrm{O}$ 型 $\quad \mathrm{AB}$ 型 & \\
\hline 13. & 尊敬する人物 & \\
\hline 14. & 好きな言葉 & \\
\hline 15. & 将来の夢 & \\
\hline
\end{tabular}




\section{練習問題}

1. Fill out the following questionnaire about yourself.

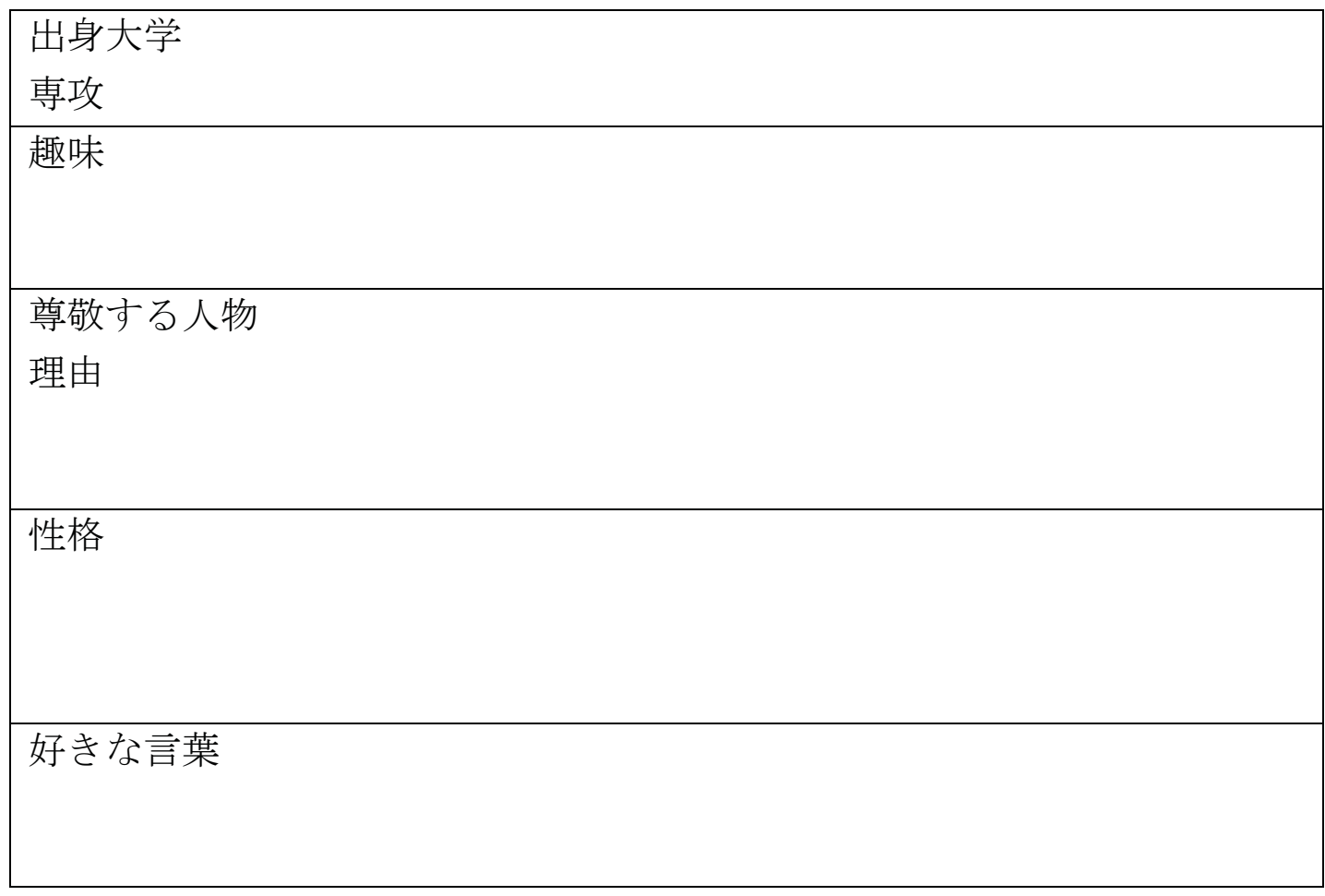

2. Translate the following into Japanese.

Portland has the population of approximately 60,000 and is said to be one of the best places to live in America.

3. Translate the following into English.

- 事務員募集中

・ ちなみに、祖父母は今ブログに凝っていて、載せる写真を一生懸命撮ってい る。

・ 将来は、どちらかというと、企業に就職して真面目にがんばるより、友だち を誘ってヨガ教室を始めたいと思っている。 
Created by Emiko Konomi 2014

4. On the basis of the self-introduction presented, answer the following questions about the person in English. You'll hear the introduction twice.

1. Name

2. Educational background

3. Work experiences

4. Hometown

5. Family

6. Additional Information

5. Translate each response to the question into English.

Q : どういう人ですか。

1.

2.

3.

4.

5

\section{まとめ}

A. Write your own self-introduction scripts, one for formal and another for casual situations.

B. Describe personalities of well-known characters and discuss how their personalities relate to their jobs and roles.

$$
\text { 参考：ネットから }
$$


Created by Emiko Konomi 2014

\begin{tabular}{|c|c|}
\hline 星座 & 誕生日 \\
\hline おひつじ座 & 3 月 21 日〜 4 月 20 日 \\
\hline おうし座 & 4 月 21 日〜 5 月 21 日 \\
\hline ふたたご座 & 5 月 22 日〜 6 月 21 日 \\
\hline かに座 & 6月 22 日〜 7 月 23 日 \\
\hline しし座 & 7 月 24 日〜 8 月 23 日 \\
\hline おとめ座 & 8 月 24 日〜 9 月 23 日 \\
\hline てんびん座 & 9 月 24 日〜 10 月 23 日 \\
\hline さそり座 & 10 月 24 日 11 月 22 日 \\
\hline いて座 & 11 月 23 日 12 月 22 日 \\
\hline やぎ座 & 12 月 23 日〜 1 月 20 日 \\
\hline みずがめ座 & 1 月 21 日〜 2 月 19 日 \\
\hline うお座 & 2 月 20 日〜 3 月 20 日 \\
\hline
\end{tabular}

血液型性格診断

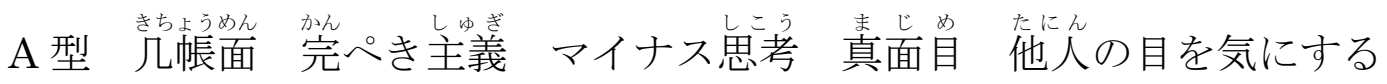

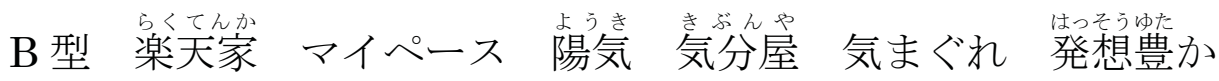
$\mathrm{O}$ 型 おおらか 人懁っこい リーダー気質 芷值 責けず嫌い情熱家

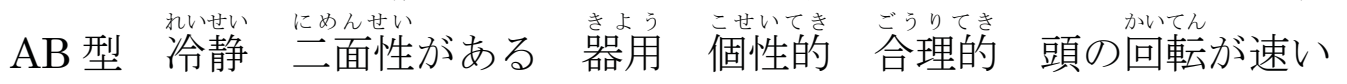
好きな性格アンケート：友だちを選ぶならどちらがいい?

1. 気が利く or 気が利かない

2. 真面目 or 不真面目

3. 馬鹿or 頭いい

4. 空気読める or 読めない

5. 人見知り or フレンドリー

6. うるさい or 大人しい

7. 明るい or 暗い

8. 優しい or 冷たい

9. お酒落or お酒落じやない

10.何考えてるか分からない or 何考えてるか分かる 
Created by Emiko Konomi 2014

\section{レッスン 2 : グローバル化}

\section{本文}

最近グローバルという言葉をよく耳にします。「グローバル企業」

とか「グローバルな時代」、また「グローバルな人材を育てよう」

とか「グローバル化が進んでいる」など、ビジネスや教育の現場で

は、普通に使われています。以前は聞き慣れない言葉でしたが、今

では知らない人はいないと言っても過言ではありません。しかし，

いったいグローバルとはどういう意味なのでしようか。

以前はよく国際化とかインターナショナルといった言葉が使われ

ていたと思います。この国際化やインターナショナルという表現は、

国境または異文化を前提にした言葉です。世界は様々な国や文化の

集まりなので、それぞれの個性を尊重し、理解し合いながら、お互

いのニーズに対応しようという考え方です。

一方、グローバルという言葉には、少し違った語感があるようで

す。グローバルとは、国境を越えて、地球を丸ごと一つのコミュニ ティーとしてとらえ、世界共通のニーズに対応しようというアプロ 一チです。

例えば、地球温暖化などの環境問題や、感染症などの医療問題、 また世界経済の問題などは、人間社会全体に影響するものです。世 界中が協力して解決しなければなりません。また、ITの発達によっ て、世界中で情報や知識や技術がリアルタイムで共有されるように なりました。そして、アップルやグーグル、マクドナルドなどのグ 


\section{Created by Emiko Konomi 2014}

ローバル企業は、世界中にほぼ同じ商品やサービスを同時に提供し ます。つまり、現代は、世界のどこにいても同じ物が手に入る、そ んな時代です。

しかし、その陰で、グローバル化によって、世界が均一化され、 コミュニティー固有の生活や産業、文化が消えてしまうのではない かと心配する声もあります。インターネットが普及し、英語が共通 語になり、英語圈の文化が世界中に広がると、文化の多様性がなく なるかもしれません。また、ビジネスがグローバル化すると、ロー カルな産業や商品は、グローバル企業との㛜しい競争の中で消えて しまい、様々な伝統や技術が失われる可能性もあります。さらに、 グローバル企業の中には、発展途上国の低賃金や人権リスクによっ て、コストを削減する所もあります。このように、グローバル化の 影響は、先進国か新興国か発展途上国かによって異なり、決して

「グローバル」ではないという事です。

今、世界は大きく変化しつつあります。世界の未来を考えるとき、 私たちは、まず国際化とグローバル化の違いをしっかり理解しなけ ればなりません。そして、グローバル化の及ぼす様々な影響を正確 にとらえ、どんな未来に向かって進みたいのか、議論する必要があ りま。

\section{表現ノート}

1. 焣にする overhear

目にする witness, come across

口にする take a taste, speak aloud 
Created by Emiko Konomi 2014

手にする take possession of

2. グローバル化 $\mathrm{X}$ 化 $\mathrm{X}$-nization

国際化 internationalization

温暖化 (global) warming

3. 聞き慣れない unfamiliar, rarely heard

Verb Stem (the ます form withoutます) + 慣れる

住名慣れた町 a town which one is used to living in

使い慣れた言葉 familiar word

見慣れない顔热 unfamiliar face

4. X といっても過言ではない it's not an exaggeration to say X

5. X を前提にする under the assumption of $\mathrm{X}$, assuming $\mathrm{X}$

結婚を前提にして付き合う date to marry

6. 理解し合う understand each other

Verb Stem + 合う do X mutually

助け合う help each other, cooperate

話し合う talk together, discuss, negotiate

7. 国境を越えて cross-border, trans-national

8. 丸る゙と entirety as it is, as a whole

9. 世界共通 universal, world-wide

$$
\mathrm{X} \text { 共通 }
$$

10. 手に入る be accessible

大金が手に入った I got a windfall.

手に入りにくい物 things that are hard to obtain

11. 均一化する homogenize

均一 homogeneous, uniformly

百宁均一 Everything is fixed at 100 yen.

12. コミュニティ一固有 community-specific

$\mathrm{X}$ 固有 $\mathrm{X}$-specific, unique to $\mathrm{X}$, inherent to $\mathrm{X}$

それは、日本語固有の表現だ。

It's an expression unique to Japanese.

13. Xによって翼なる vary depending on X 
Created by Emiko Konomi 2014

異なる is more formal than違う

14. 変化しつつある be in the process of changing

Verb Stem+つつある be in the process of $\mathrm{X}$

変わりつつある It's changing.

増えつつある It's increasing.

15. 影響を及ぼす affect, influence

$\mathrm{X}$ に影響を与ち

X に影響を受ける get affected by X

Answer the following questions in Japanese ORALLY. These questions are recorded on the audio. Do not look at the script as you listen to the audio. The script is here to help you only when you cannot comprehend the questions by listening alone.

1.グローバルという言葉はどんな風に使われていますか。

2. どんな人がグローバルという言葉を良く使いますか。

3. 教育の現場というのは、例えばどんな所でしょうか。

4.グローバルという言葉を知らない人もいますか。

5. 以前はどんな言葉がよく使われていましたか。

6. その言葉はどういう考え方を前提にしていますか。

7. 国際化とはどういう意味ですか。

8. グローバルとは、どういうアプローチですか。

9. グローバルな問題とはどんな問題ですか。例を三つあげてくださ V。

10. グローバル化によって、世界はどう変わりつつありますか。

11. IT の発達とグローバル化にはどんな関係がありますか。 
Created by Emiko Konomi 2014

12. グローバル企業とはどんな企業ですか。アップル、グーグル マクドナルド以外のグローバル企業をあげてください。

13. 世界が均一化されるというのはどういう意味ですか。

14. どうして文化の多様性がなくなると心配しているのですか。

15. グローバル化の中で、ローカルな企業や産業はどうなりますか。

16. 企業はコスト削減のために色々な事をしますが、ここで心配さ れているのはどんな事ですか。

17.人権リスクとは、例えばどんな事でしようか。

18. 先進国、新興国、発展途上国の例をあげてください。

19. グローバル化の影響は「グローバル」ではないというのは、ど ういう意味でしょうか。

20. どうして「」、カギかつこを使ったのでしようか。

21. 世界の未来を考えるとき、まず何をしなけれげなりませんか。

\section{\&ドリル}

Listen to the audio. Respond to each cue, following the first two model exchanges.

A. このことば、よく聞きます?

いや、聞き慣れないことばなので、ちょっと。 あの人、よく見ます?

いや、見慣れない人なので、ちょっと。

1. この漢字、よく書きます?

2. あのアプリ、よく使います?

3. この野菜、よく食べます?

4. こんな薬、よく飲みます?

5. この道、よく歩きます?

B. 知らない人はいませんね。 


\section{Created by Emiko Konomi 2014}

世界共通ですね。

ええ、知らない人はいないと言っても過言ではありませんね。 ええ、世界共通と言っても過言ではありませんね。

1. 普通に使われていますね。

2. 異文化ですね。

3. 人間社会全体に影響しますね。

4. 世界のどこにいても同じ物が手に入りますね。

5.世界が均一化されてきましたね。

C. 理解しましたか。 はい、お互いに理解し合いました。 話しましたか。はい、お互いに話し合いました。

1.助けましたか。

2. 協力しましたか。

3. 教えましたか。

4. 喜びましたか。

5. 議論しましたか。

D.グローバル化が進みますか。

はい、グローバル化が進むのではないかと心配しています。 英語が共通語になりますか。

はい、英語が共通語になるのではないかと心配しています。

1. 地球温暖化が進みますか。

2. 感染症が広がりますか。

3. 文化の多様性がなくなりますか。

4. 地域固有の伝統が消えますか。

5.世界中が均一化しますか。

E. だれでも同じですか。いや、人によって異なりますね。 どの国でも同じですか。いや、国によって異なりますね。

1.どの地域でも同じですか。

2. どんな感染症でも同じですか。

3.どんな環境でも同じですか。

4.どの文化でも同じですか。

5. どの商品でも同じですか。

F、変化しませんね。いや、少し変化しつつありますよ。 増えませんね。いや、少し増えつつありますよ。 
Created by Emiko Konomi 2014

1.広がりませんね。

2. 共有されませんね。

3.なくなりませんね。

4. 影響、受けませんね。

5.手に入るようになりませんね。

リスニング練習

Listen to the audio. Indicate whether or not each statement is in line with the main text by marking O (マル: Correct) or X (バツ Incorrect or Undeterminable). Explain in English why you marked an item incorrect or undeterminable.
1. ___ 2
3.
4.
5.
6.
7.
8.
9.
10.

Listen to the audio for the correct reading of each kanji. Try reading the Kanji yourself during the first pause, listening to the correct reading, and then repeating after the model during the second pause.
1. 最近
recently
2. 言葉
language
3. 企業
corporation
4. 人材
personnel
5. 現場
scene
6. 過言
exaggeration
7. 語感
nuance
8. 表現
expression
9. 国境
national border
10. 理解
understanding
11. 固有
characteristic
12. 地域
region
13. 異文化
cross culture 
Created by Emiko Konomi 2014

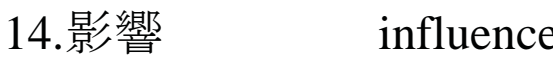

15.協力 cooperation

16. 前提 premise

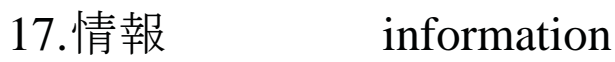

18.技術等 technology

19. 知識 knowledge

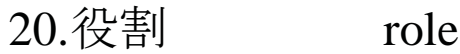

21. 発達 development

22. 普及 spread

23. 同時 concurrent

24.産業 industry

25. 商品 commodity

26. 競争 competition

27.末来 future

28. 尊重する respect

29. 共有する share

30. 対応する correspond

31. 提供する offer

32. 削減する cut, reduce

33. 英語圏

English-speaking regions

34.多様性

diversity

35.均一化 homogenization

36. 共通語等 common lang.

37.新興国 emerging nation

38. 先進国 developed nation

39. 発展途上国 developing nation

40.感染症 infectious disease

41. 地球温暖化 global warming

42. 環境 environment

43. 医療 medical care 
Created by Emiko Konomi 2014

44. 賃金

45. 人権

46. 筑く

47.越える

48.失う

49.㛜しい

50.異なる wages

human rights

build

cross over

lose

severe

differ

\section{ぬみなの一言}

A. グローバル化というのは、つまり「世界は一つ、人類はみんな 家族」という事でしょう? 大賛成です。ちよつと楽観的かもし れませんけど、将来、戦争もなくなるかもしれませんね。

B. 地球温暖化は，世界中が協力しないと解決しないので、国境を 越えて、知識や技術を共有して解決するべきです。テロの問題も、 感染症も、世界経済も、世界中が一つになってがんばれば、解決 できますよ。甘いですか?

C. 世界共通のニーズに対応するためには、やはりグローバルな視 点が必要です。でも、それぞれの地域固有のニーズはどうなるん でしようか。将来の子ども達のためにも、地域の伝統や文化を守 るのは私たちの責任だと思います。

D. 生活や文化が均一化するのは、反対です。世界中が英語をしや ベって、マクドナルドのハンバーガーを食べて、ハリウッドの映 画を見るなんて、想像しただけで、ぞっとします。文化の多様性 こそ、人類の遺産です。しつかり守りたいですね。 


\section{Created by Emiko Konomi 2014}

E. ビジネスの世界では、グローバルな人材を探しています。世界 のどこででも、だれとでも仕事ができる人材です。最近、楽天が、 英語を公用語にしましたけど、やっぱり英語が出来なくちや、グ ローバルな仕事はできません。でも、英語さえ出来ればいいとい う訳じゃなくて、やっぱり専門分野の知識や技術がしっかりして いる人が必要なんです。

F. 若者には、どんどん海外に出て、世界を見てほしいですね。国 内にいると考え方も狭くなるし、人間もガラパゴス化しちゃうで しょう? 最近、留学する学生が減りつつあるそうですけど、な ぜでしょう? 国内で勉強しただけで、国際経験のない人は、ビ ジネスの現場では、使えませんよ。

G. この厳しい経済競争の中で、世界に通用するインターナショナ ルな人材を育てるのは、国や大学や企業の責任です。もっと外国 人留学生や研究者を増やしたり、外国の大学や企業と協力したり する必要があると思います。国籍を越えて、世界の優秀な人材を 日本に迎えるべきです。

H. グローバル化って、最終的には先進国が他の国にああしろ、こ うしろって言うという事でしょう。確かに、貧しい発展途上国は、 生活水準が上がるかもしれませんけど、先進国のライフスタイル や価值観を押し付けられて、しあわせでしょうか。余計なお世話 つて感じです。最近、新興国では、うつ病が増えているそうです が、グローバル化の影響だと思います。実際、しあわせのグロー バル化なんて、不可能ですよ。 
Created by Emiko Konomi 2014

\section{みんなの一言 表現ノート}

1. ザい

2. ぞっとする

3. ガラパゴス化

4. 通用する

5.押し付ける

6. 余計なお世話 nä̈ve, too optimistic

考え方が甘いＨis thinking is too naïve.

creepy, get filled with horror

Galapagosization (Galapagos has many endemic species)

becoming isolated and idiosyncratic, and therefore unsuccessful in the outside world

measure up to required standards, pass muster, acceptable, usable 世界に通用する world-class

仕事に通用しない日本語 Japanese that is not useful in work

force something onto a person

Mind your own business. (lit. unnecessary care)

\section{練習問題}

A. Circle the MOST appropriate item for each blank. (10)

1. そう言っても ではありません。

2. それぞれの個性を しましょう。

3. 地球温暖化などの 問題について話した。

4. 世界のどこにいても同じ が手に入る。

5. 大きい会社との 競争の仲で、消えた。

6. グーグルは世界中に同じサービスを している。 できるようになった。

7. インターネットで知識を つつある。

8. 世界は今大きく が消えてしまう。可能性

9. 世界が均一化され、文化の 慣れない言葉ですね。

過言 言葉 語感 表現

発達 尊敬 教育 尊重

経済医療情報環境

商品 産業 人権 伝統

広い 明るい厳しい低い

提供 影響 削減 前提

共通 共有 協力 普及

変化 変わる 変え 変わり

10.これは あまり 使う使って使い 使え 
Created by Emiko Konomi 2014

B. Translate into Japanese.

We need to first understand the difference between globalization and internationalization.

C. Translate into English.

1. 英語圏の文化が広がっても、発展途上国の地域固有の文化は失われないと いうのは楽観的だ。

2. 人間社会全体のニーズに対応しない国は、先進国でも、ガラパゴス化する。

D. Listen to the audio and translate each response to the question into English.

$$
\text { グローバル化についてどう思いますか. }
$$

1.

2.

3.

4.

5.

\section{まとめ}

A. Summarize the difference between Internationalization and Globalization as discussed in the main text.

B. How does globalization affect different countries and communities?

C. Discuss pro's and con's of globalization, and state your opinion as to in what direction the world should head and why.

\section{参考：上級スタイル}

How would the main text look in a different writing style? The fifth paragraph from the main text, for example, can be rewritten in a more expository style at an advanced level. Compare the two. 


\section{Created by Emiko Konomi 2014}

しかし、その陰で、グローバル化によって、世界が均一化され、 コミュニティー固有の生活や産業，文化が消えてしまうのではない かと心配する声もあります。インターネットが普及し、英語が共通 語になり、英語圈の文化が世界中に広がると、文化の多様性がなく なるかもしれません。また、ビジネスがグローバル化すると、ロー カルな産業や商品は、グローバル企業との厳しい競争の中で消えて しまい、様々な伝統や技術が失われる可能性もあります。さらに、 グローバル企業の中には、発展途上国の低貨金や人権リスクによっ て、コストを削減する所もあります。このように、グローバル化の 影響は、先進国か新興国か発展途上国かによって異なり、決して 「グローバル」ではないという事です。

\section{上級レベル}

しかし、反面、グローバル化に伴い世界の均一化が起き、個々の 地域社会固有の生活様式や産業、文化等が消滅の危機にさらされる 可能性を危惧する議論もある。インターネットの普及、英語の共通 語化、英語圈文化の浸透により、現存する文化の多様性は、その存 続を劦かされかねない。また、グローバル化した世界企業が各地に 進出するに従い、地域の既存の産業や商品は、グローバル企業との 熾烈な競争に敗退し、その結果、長年築き上げられてきた様々な伝 統や技術も消失の危機を迎える恐れもある。さらに、グローバル企 業が、搾取とも非難されかねない低賃金と労働条件のもとで、発展 途上国の労働者を雇用し、中には人権リスクを犯してまで、生産コ 
Created by Emiko Konomi 2014

スト削減を罒ろうとしている事例も報告されている。以上のように、 グローバル化の影響は、先進国、新興国、発展途上国の間で、顕著 な格差を呈し、「グローバル」と言う語感が示唆する汎世界的な共 通性や公正さを伴っているとは決して言えないのである。

1. Describe how this advanced level text is generally different from the main text.

2. List pairs of equivalent expressions from this version and the main text.

\section{模擬試験}

A. Circle the MOST appropriate item for each blank and translate the entire sentence. (30)

1. テストがあるので 勉強している。最も 真面目 一生懸命 謙虚

2. なので、小さい事は気にしない。 楽観的 心配性 自己中 人見知り

3. ブログに 写真です。

着せる 乗せる 見せる 載せる

4.お互いに 合いましょう。

助け 助ける 助かり 助かって

5. IT 企業に したいと思っています。

仕事 募集 就職 留学

6. これはだれが撮った ですか。 血液 写真 商品 ブログ

7. 自分の を押し付けてはいけない。 価值観 血液型 可能性 感染症

8. この を耳にした事ありますか。 過言 文学 語感 表現

9. エイズなどの 問題について話した。 経済 医療 情報 環境 
Created by Emiko Konomi 2014

10. 伝統が かもしれない。

11. は、作家になりたいと思う。

12. 生活水準が つつある。

13. 考え方が 人はおおらかだ。

14. 今ョガに います。

15. 出身は日本だが、 はアメリカだ。
失う失われる 失わせる 失い

趣味 将来 未来 予定

E. Based on the written material, answer the questions in English. (20)

私は子どものときから、人と競争するのがきらいで、だれとでも仲よくやっ てきました。社交的というか、人見知りしない性格だし、人間はみんな家族 だと思っているので、異文化の人とも、国籍を越えて、わかり合える自信が あります。専攻は環境学です。地球温暖化問題を解決するための知識や技術 を勉強しています。

1. What is her major? (2)

2. What specific things does she study? (6)

3. She is applying for a position as cultural ambassador to work in developing countries. How does she explain her qualifications for the position? List all. (12)

F. Listen to the audio and translate each response into English. (30)

$$
\text { インターネットの影響は? }
$$

1.

2.

3.

4. 
Created by Emiko Konomi 2014

5.

6.

G. Writer in Japanese. (20)

グローバル化と国際化の違いを説明してください

今アメリカの子ども達に最も尊敬されている人はだれでしょうか。 じうしてでしょうか 
レッスン 3: 絆

\section{\&本文}

東日本大震災

2011 年 3 月 11 日、東日本をマグニチュード 9.0 の巨大な地震と津 波が襲った。2 万人近い人々が死亡し、数十万人の人々が被災した。 また、首都圈では電車が止まり、400 万人が帰宅困難者となった。福 島では、深刻な原発事故が起き、地域は放射線に污染され、住民は 避難せざるを得なくなった。さらに、電力が不足したため、全国で 厳しい節電が行われた。

震災後の日本は、復旧、復興と共に原発の事故処理、今後のエネ ルギー政策、防災の強化など、課題が山積している。一方、震災を きっかけに、生き方を見直し、人と人とのつながり、いわゆる絆を 大切にしようとする人々が増えたと言われている。

\section{表現ノート}

1. 2 万人近い人々 almost 20,000 people

この仕事は、二時間近くかかった。

This work took me almost two hours.

この原発では、もう五回近く事故が起きている。

At this nuclear plant, there have been almost five accidents.

2. 数十五人 tens of thousands of people

数十人 dozens of people (between 20 to 90 people)

十数人 over ten (less than 20) people

あの人には、数回会った事がある。 
I met that person several times.

数日後A few days later

3. 困難（な） difficult/hard

$\mathrm{X}$ 困難 hard to do X ( $\mathrm{X}$ is usually a two-Kanji word)

$\mathrm{X}$ 困難者 person who has difficulty doing $X$

㷌宅困難者 people unable to return home (after earthquake,

etc.)

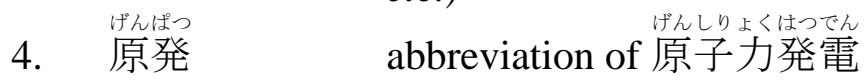

原子力 nuclear power

発電 generating electricity

はっでんしょ

発電所 power station

だっげんぱっ

脱原発 abandoning nuclear power generation

5. 避難せざるを得ない have no choice but to evacuate

・〜ざる : To make this negative form of the classical Japanese, replace -nai with -zaru of the informal negative form of verbs ( except for する).

$$
\begin{array}{ll}
\text {-ru verbs: } & \text { 食べざる } \\
\text {-u verbs: } & \text { 飲まざる } \\
\text { irregular verbs: } & \text { 来ざる } \\
& \text { せざる（NOT しざる） } \\
\text { 見ざる、聞かざる、言わざる }
\end{array}
$$

See no evil, hear no evil, and speak no evil

・〜ざるを得ない： have no choice but to do X

6. 復興と共に along with recovery

- Xとともに together with X/simultaneously as X happens

言葉とともに、文化も勉強している。

I'm studying the culture along with the language.

- If $\mathrm{X}$ is a verb or an adjective, it must be in the non-past form.

事故が起きるとともに、地域は污染された。

Along with the accident occurring, the area got polluted.

7. 山積している be piled up

仕事が山積している。There is a pile of work.

山積する課題を、一つずつ処理して行く。

I'll take care of the mounting issues, one at a time.

8. 震災をきっかけに because of the earthquake / the earthquake as the catalyst 
きっかけ a trigger to do something

どんなきっかけで、日本語を勉強しはじめたんですか。

9. いわゆる X

How did you start studying Japanese?

so-called $X$

読解チェック

Answer the following questions in Japanese ORALLY. These questions are recorded on the audio. Do not look at the script as you listen to the audio. The script is here to help you only when you cannot comprehend the questions by listening alone.

1. 2011 年 3 月 11 日の地震は何と呼ばれていますか。

2. その地震の大きさは?

3. 津波はどこを襲いましたか。

4. 死亡者の数は?

5. 被災者の数は?

6. 地震後、どうして人々は原発に近い地域に残る事が出来なかっ たのですか。

7. 帰宅困難者というのはどういう意味ですか。

8. 首都圈とは、どこですか。

9. 首都圈では，どんな地震の影響がありましたか.

10．被災地以外の所には、どんな影響がありましたか。

11. 節電のためには、どんな事をしたらいいのでしょうか。

12. 震災後の日本にはどんな課題がありますか?

13. 震災後、人々はどう変わったと言われていますか。

14.それは，どうしてだと思いますか。 
15.あなたの住んでいる地域は、地震や津波に襲われた事がありま すか。

\section{ダリル}

A. 約百人の人が来ましたね。抆、百人近い人が来ました 約一週間待ちましたね。㸚。い、一週間近く待ちました。

1. 約一万冊の本がありますね。

2. 約八時間、電車が止まりましたね。

3. 約五日、電話が通じませんでしたね。

4. 約二十個の箱が届きましたね。

5. 約二千万円のお金が集まりましたね。

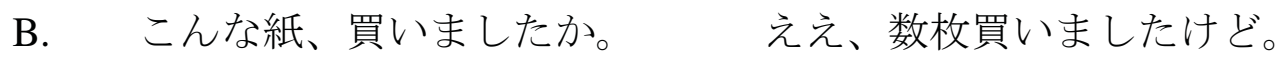
こんな店、見ましたか。 ええ、数件見ましたけど。

1.こんな学生、いますか。

2.こんな車、ありますか。

3.こんな本、出ていますか。

4.こんなスーツ、持っていますか。

5.こんな写真、撮りましたか。

C. 避難したんですか.

はい、避難せざるを得なかったんです。 エネルギー政策を変えたんですか。 はい、変えざるを得なかったんです。

1. 生き方を見直したんですか。

2. 友だちを誘ったんですか。

3. 節電したんですか。

4.みんなとうまくやったんですか。

5. 歩いて䚻ったんですか。

D. 就職してから、車を買ったんですか。 はい、就職をきっかけに、車を買ったんです。 地震が起きてから、生き方を見直したんですか。

はい、地震をきっかけに、生き方を見直したんです。 
1. 事故があってから、原発に反対しているんですか。

2. 地球温暖化が進んでから、節電し始めたんですか。

3. 空気の污染がひどくなってから、引っ越ししたんですか。

4. 結婚してから、会社を辞めたんですか。

5. 東日本大震災があってから、絆を大切にするようになったんですか。

E. 人と人とのつながりです。

ああ、いわゆる絆ですね。

世界中で同じ商品を提供する会社です。

ああ、いわゆるグローバル企業ですね。

1. バスや電車が止まって、家に帰れなくなった人たちです。

2. 地球が温かくなっている事です。

3. かっこいい男の人です。

4. 一つの事にものすごく詳しくて、他の事に興味がない人です。

5. 回りの人たちが何を考えているか理解できないことです。

F. いわゆる絆です。

つまり、人と人とのつながりという事ですね。

いわゆる地球温暖化です。

つまり、地球が温かくなっているという事ですね。

Rephrase the following in your own words.

1.いわゆるガラパゴス化です。

2. いわゆる自己中な人です。

3.いわゆる古いエネルギー政策です。

4. いわゆるグローバルなアプローチです。

5. いわゆる脱原発です。

リスニング練習

Listen to the audio. Indicate whether or not each statement is in line with the main text by marking $\mathrm{O}$ (マル: Correct) or X (バツ Incorrect or Undeterminable). Explain in English why you marked an item incorrect or undeterminable.

1.

2.

3.

4.

5.

6.

7.

8.

9.

10. 
Listen to the audio for the correct reading of each kanji. Try reading the Kanji yourself

during the first pause, listening to the correct reading, and then repeating after the model during the second pause.

1. 東日本 eastern Japan

2. 西日本 western Japan

3. 地震 earthquake

4. 津波 tsunami / tidal wave

5. 巨大 huge / gigantic

6. 襲う to attack/to assail

7. 死亡する to pass away

8. 数十万 hundreds of thousands of

9. 被災する to be a victim of [some disaster] or to suffer from

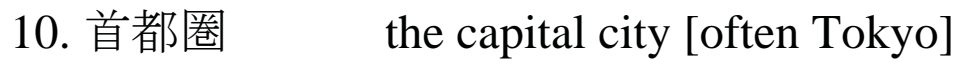

11. 帰宅 returning home

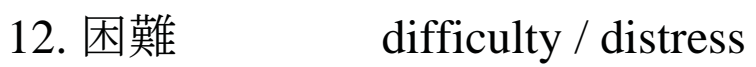

13. 帰宅困難者 travelers who have difficulty returning home

[esp. after an earthquake]

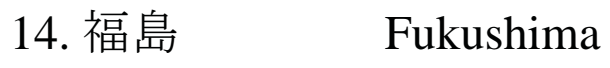

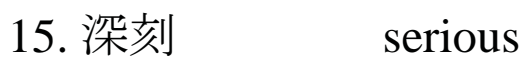

16. 原発 nuclear power plant / nuclear power supply

17. 原発事故 nuclear power plant incident

18. 地域每等ion

19. 放射線年 radiation

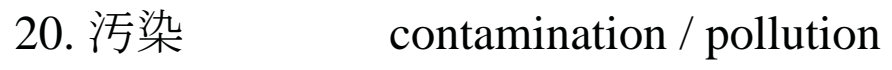


21. 住民 citizens / residents

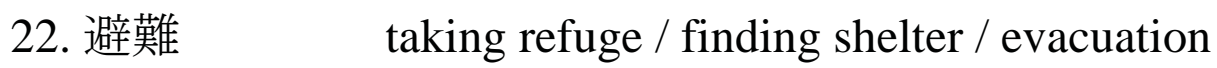

23. 震災後等 post-quake / after the earthquake

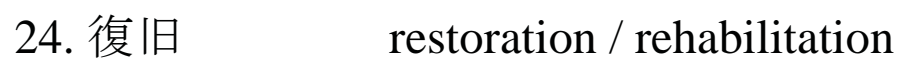

25. 復興 revival / reconstruction

26. 共に together

27. 処理 processing / dealing with

28. 政策 political measures / policy

29. 防災花然aster prevention

30. 山積する lying in piles / forming piles

\section{ぬみんなの一言}

東日本大震災後、ツイッターに投稿された心に残る言葉

一部 prayforjapan.jp より引用

1. 暗すぎて今まで見た事もないくらい星がきれいだよ。仙台のみん

な、上をむくんだ。

2. 停電するとそれを直す人がいて、断水すると、それを直す人がい

て、原発で事故が起きると、それを直しに行く人がいる。勝手に 
復旧している訳じやない。僕らが室内でマダカナーとか言ってい

る間、クソ寒い中で死め気でがんばってくれている人がいる。

3. ぜんぜん寝ていないであろう旦那に、「大丈夫? 無理しないで」

とメールした。「自衛隊なめんなよ。今無理しないで、いつ無理

するんだ? 言葉に気をつけろ。」と返事が。

4. 駅員さんに「きのうは一生懸命電車を走らせてくれてありがとう」

って言っている小さな子どもたちを見た。駅員さんは泣いていた。

俺は号泣していた。

5. M9.0 世界最大級となったのか。じや、今後復興のための工ネル ギーも愛も世界最大級にしなくちや。

6. 避難所のおじさんが「これからどうなるんだろう」ともらしたと

き、横にいた高校生ぐらいの男の子が「大丈夫、大人になったら

僕らが絶対戻します」って背中をさすってたらしい。大丈夫、未 来あるよ。

7. 子どもがお菓子を持ってレジに並んでいたけれど、順番が近くな り、レジを見て考え込み、レジ横にあった募金箱にお金を入れて、 
お菓子を棚に戻して出て行きました。店員さんがその子どもの背 なかにむけてかけた「ありがとうございます」という声が震えて いました。

8. ホームで待ちくたびれていたら、ホームレスの人たちが寒いから 敷けって、段ボールをくれた。いつも私たちは横目で流している のに、暖かいです。

9. 4 時間の道のりを歩いて帰るときに、トイレのご利用どうぞ！と 書いたスケッチブックを持って、自宅のお手洗いを解放している 女性がいた。日本って、やはり世界一暖かい国だよね。あれ見た 時は感動して泣けてきた。

10.物が散乱しているスーパーで、落ちているものをていねいに拾い、 そして列に黙つて並んで、お金を払つて買い物をする。 運転再開した電車で、混んでるのに、妊婦に席を譲るお年寄り。 すごいよ、日本。

11.バイト中に地震があって、ほぼ満席の状態からお客さんに外に避 難してもらいました。食い逃げ、半端ないだろうな、と思ってい 
たが、ほとんどのお客さんが戻ってきて会計してくれました。ほ んの少しの戻られなかったお客さんは今日わざわざ店に足を運ん でくださいました。日本て、いい国。

12. 韓国人の友達からさつききたメール。「世界唯一の被曝国。大戦 にも負けた。毎年台風がくる。地震だってくる。津波もく る・・・小さい島国だけど、それでも立ち上がってきたのが日本 じやないの。頑張れ、超頑張れ。」ちなみに僕いま泣いている。

13. 国連からのコメント「日本は今まで世界中に援助してきた援助大 国だ。今回は国連が全力で日本を援助する。」

14.“ Operation Tomodachi” 米軍による救助活動名

15.震災でお亡くなりになった方々に、心よりご冥福をお祈りすると 共に、被災された方々に、謹んでお見舞い申し上げます。

$$
\text { みんなの一言 表現ノート }
$$

1. 心に残る unforgettable, staying in one's heart

2. クソ寒い damn cold (coll.)

3. 死ぬ気で determined to do or die、 with greatest determination 
4. なめんなよ Don't take X lightly/Don't underestimate X/Don't mess with me なめる underestimate, make light of

The verb endings of $る$ and $ら$ become $ん$ in casual speech. わかんの? So, do you understand?

わかんない don't understand

つまんない boring

5. 最大級

largest

世界最大級 world's largest

6. 待ちくたびれる get tired after waiting / long-awaiting

7. 横目で流す

8. 半端ない

glance sideways and ignore / not get involved/indifferent

not half-measures, to a great extent (coll.)

半端 odds and ends

9. 整を運ぶ、 visit/go to visit

10. 世界一 world's best

にっぼしいちたか

日本一高いビル the tallest building in Japan

アメリカーのフットボールチーム

the best football team in America

ポートランドーおいしいレストラン

the best restaurant in Portland

11. 席を䇏る

give up a seat for someone

讓る give away/ compromise/ pass on

ち上らがんぱ

12. 超頑張れ Try extra hard! (Coll.)

超 $\mathrm{X}$ very $X$

超おいしい extremely delicious

13. 援助大国 foreign aid super power

大国 big power

けいぜいたいこく

経済大国 economic power/ economic giant

14. ご冥福をお祈りします。May the deceased rest in peace.

15. 謹んでお見舞い申し市げます。I extend my sincere sympathy.

謹んで respectfully/humbly

お見舞い token of sympathy / visit to express sympathy 


\section{練習問題}

A. Circle the MOST appropriate item for each blank. (10)

1. 生き方を ざるを得ない。

見直し 見直さ 見直せ 見直す

2. 結婚 きっかけに、仕事を辞めた。

がでををに

3. 地球温暖化など な問題について話した。

深刻厳しい 最大級 勝手

4. 二万人 人々が家を失った。

近く 近い 近くて 近さ

5. あの若者は、まだ だろう。 数十年 数十才 十数才 約十才

6. むずかしい課題を しなければならない。 処理 政策 強化 復旧

7. に協力してください。

断水 停電 節電 電力

8. 心に残る言葉に して、涙が流れた。 感動 援助 無理 お見舞い

9. 韓国も日本も のメンバーである。 米軍自衛隊 島国 国連

10.レストランで食べた後、 するのはよくない。募金 食い逃げ 会計 解放

B. Describe what happened in Japan on March 11, 2011, including the earthquake, tsunami, Fukushima nuclear plant incident, radiation contamination, evacuation, and impact on the C. capital city area and the entire country.

D. Listen to the audio and translate each response to the question in to English.

1.

2.

3.

4.

5.

6.

7. 


\section{まとめ}

A. Tweet a heart-warming incident you witnessed.

B. Describe your own life-changing experience.

\section{参考：図表}

In this section, we will practice making PowerPoint presentations including charts and graphs. Study the narratives below that accompany the charts. Following these examples, write a narrative for a chart/graph to present. You need to use the speech styles appropriate for orally presenting in the particular setting.

原発再開に関するアンケート

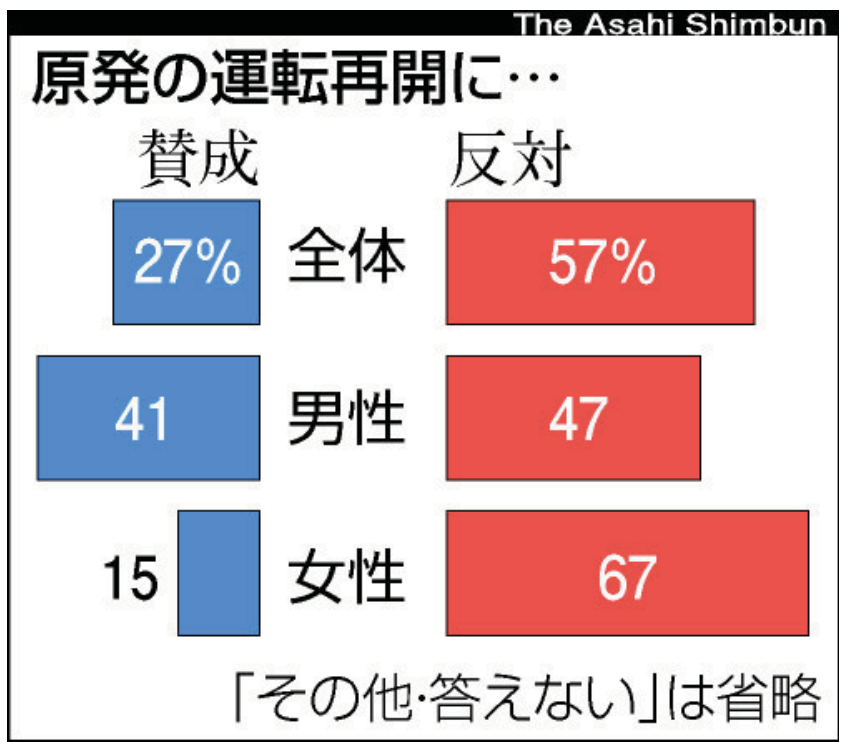

朝日新聞社 全国世論調查（電話）

朝日新聞社が 10 日に実施した全国世論調査によると、停止中の原 発の運転を再開することに $57 \%$ が反対し、賛成の $27 \%$ を大きく 上回った。原発の再開賛否は、男女の違いが目立つ。男性は賛成 4 $1 \%$ 、反対 $47 \%$ と、それほど賛否の差がないのに対し、女性は賛 成 $15 \%$ 、反対 $67 \%$ で差が大きい。 
主要国のエネルギー源構成(2008年)

1 次供給エネルギー
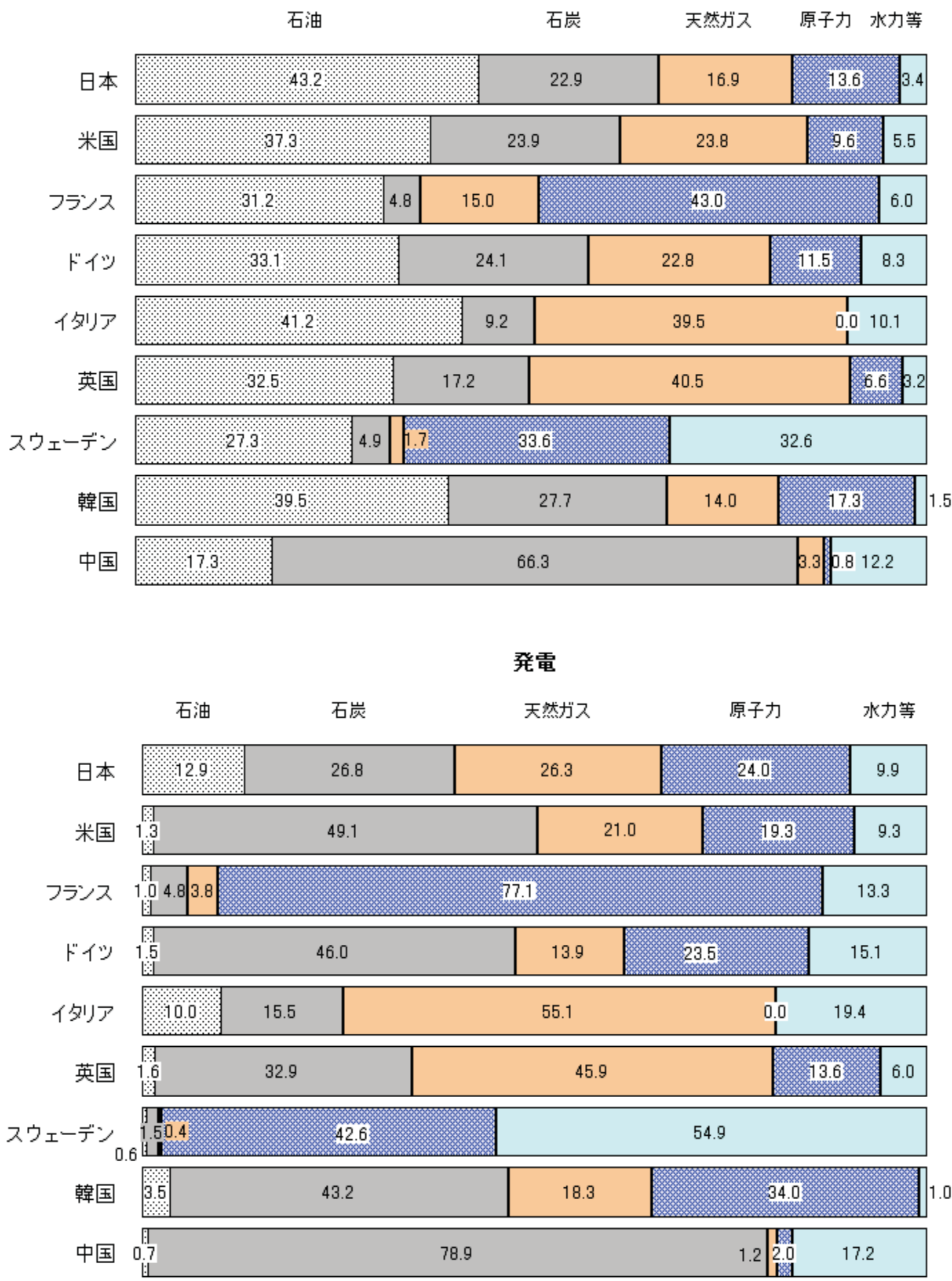

（注）発電によ自家発電、コージェネを含む。中国には香港を含む。水力等には太陽光、地熱、廃棄物等を含む。 (資料) IEA,"Energy Balances of OECD Countries 2010","Energy Balances of non-OECD Countries 2010 " 
エネルギー源の構成を主要国で比較した図である。

エネルギー源の構成で日本が目立っているのは、以下の点である。

(1)石油依存度が、イタリア、韓国と並んで高い（日本が最も高い）。

(2)天然ガスの比率が比較的小さい。

(3)原子力の比率が、フランス、スウェーデン、韓国に次いで高い。

E. 発電源の構成で日本が目立っているのは、以下の点である。

(1)フランスでは原子カが $77.1 \%$ と非常に大きく、中国は石炭が $78.9 \%$ 、米国 やドイツでも石炭が半分近く、といった片寄りが見られるのに対して、日本 は、様々な発電源を組み合わせた構成になっている。

(2)天然ガスは 1 次供給エネルギー構成よりも、発電源としての方が大きい。 (3)原子力の比率が、フランス、スウェーデン、韓国に次いで高い。 
レッスン $4:$ 吾輩は猫である

\section{\&本文}

『吾輩は猫である』は、1905 年から 1906 年まで雑誌『ホトトギ ス』に発表された夏目漱石の処女小説である。中学校の英語教師、 珍野 苦沙弥（ちんのくしゃみ）の家に飼われている猫である主人公

「吾輩」の視点から、珍野家の家族や、そこに集まる人々を風刺的 に描いている。珍野苦沙弥は、漱石自身がモデルとされている。

\section{『吾輩は猫である』}

夏目漱石

吾輩は猫である。名前はまだ無い。どこで生れたかとんと見当が つかぬ。

吾輩の主人は滅多に吾輩と顔を合わせる事がない。職業は教師だ そうだ。学校から帰ると終日書斎に入ったきり、ほとんど出て来る 事がない。家のものは大変な勉強家だと思っている。当人も勉強家 であるかのごとく見せている。しかし実際はうちのものがいうよう な勤勉家ではない。吾輩は時々しのび足に彼の書斎をのぞいて見る が、彼はよく昼寝をしている事がある。時々読みかけてある本の上 によだれをたらしている。彼は胃弱で皮膚の色が淡黄色を帯びて弾 力のない不活溌な徵候をあらわしている。そのくせに大飯を食う。 大飯を食った後でタカジヤスターゼを飲む。飲んだ後で書物をひろ 
げる。二三ページ読むと眠くなる。よだれを本の上へたらす。これ が彼の毎夜繰り返す日課である。吾輩は猫ながら時々考える事があ る。教師というものは実に楽なものだ。人間と生れたら教師となる に限る。こんなに寝ていて勤まるものなら猫にでも出来め事はない と。それでも主人にいわせると教師ほどつらいものはないそうで、 彼は友達が来る度に何とかかんとか不平を鳴らしている。

\section{表現ノート}

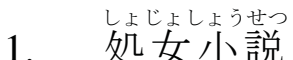

1. 処女小説 a first novel (virgin novel)

2. 飼う

keep (pets: animals, fish, birds, insects)

犬を飼っている。I have a dog.

3. 見当がつか女＝見当がつかない have no idea, can only make a wild guess ぬ is a negative ending for verbs in classical Japanese that is the equivalent of ない。

4. 滅多に〜ない almost never, rarely (Negative)

5. 顔を合わせる run into

6. 入ったきり Verb ( Past) + きり no change after X happened, 約束したきり、何もしてくれない。

He promised all right but that's it; he wouldn't do anything. 朝ご飯を食べたきり、一日中何も食べていない。 I ate breakfast, but that's it; I haven't eaten anything all day.

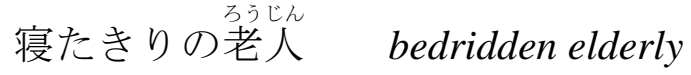

7. 勉強家であるかのごとく as if he is a hard worker

Xかのごとく(expository)、Xかのように as if X 日本人であるかのごとく、話す。

He speaks as if he is a Japanese person.

8. 読みかける start to read (unfinished)

V-stem +かける

言いかけて止めた。He started to say something but stopped. 飲みかけのコーヒー unfinished coffee メールを書きかけたが，消した。 I started writing an email, but erased it. 
書きかけのメール composed but unfinished email

9. Xのくせに in spite of $X$, although $X$

implying denunciation (so be careful!)

子どものくせに、大人のような話し方をする。

Although she is a child, she talks like an adult.

うれしくせに、うれしいと言わない。

Although he is happy, he wouldn't say it.

すると言ったくせに、しない。

Although she said she would do it, she doesn't.

10. X と生まれる born to be $X$, born as $X$

と is a formal equivalent of に. Thus, $X$ となる、X とする

are formal equivalents of $X$ になる and $X$ にする

11. $\mathrm{X}$ に限る $X$ is the best, nothing is like $X$, nothing beats $X$

暑い日はビールに限りますね。

In a hot day, beer is the best.

旅行するなら、京都に限る。

If you travel, no place is like Kyoto.

12. X にいわせると If you let X speak, X would say, According to X,

ここのすしは有名だけど、日本人に言わせるとまずいそうだ。

Sushi here is famous, but Japanese people would say it's terrible.

こんなホテルはめずらしいそうだが、私に言わせると普通だ。

They say this kind of hotel is extraordinary but I would say it's just average.

\section{読解チェツク}

Answer the following questions in Japanese ORALLY. These questions are recorded on the audio. Do not look at the script as you listen to the audio. The script is here to help you only when you cannot comprehend the questions through listening alone.

1.この作品の作家は、だれですか。

2. この作品が発表されたのは、今から何年ぐらい前ですか。

3. それはどんな時代だったでしょうか。

4. ホトトギスというのは何ですか。

5. 主人公の名前は何ですか。 
6. 家の主人の名前は? どういう意味でしょうか。

7. 猫が自分で見た事ではなく、人から聞いたらしい情報が二つあ ります。それは何ですか。

8. 猫はそれを信じていますか。

9. 家の主人の名前、職業、家族、趣味、性格を教えてください。

10.この主人の健康状態は?

11.タカジヤスターゼというのは何でしょうか。

12. 猫の視点から見た主人の日課を説明してください。

13. 家族との関係は?

14. 主人の職業について、猫と主人は感じ方が違うようです。 どう違いますか。

15. 主人の性格につて、猫と家族は見方が違うようです。 ゼう違いますか。どうして違うのでしょうか。

16. 猫はこの主人を尊敬していますか。どうしてですか。

17. この猫は、どんな性格だと思いますか。

18.この小説は何を風刺しているのでしょうか。

19. 特に風刺的な所を説明してください。

20. 猫の視点からではなく、家族や主人の視点から書くと、どう なるでしょうか。

\section{•ドリ}

A. よくすし食べるでしょう?

いや、滅多に食べないですね。

よく顔を合わせるでしょう?

いや、滅多に合わせないですね。

1. よく地震起きるでしょう?

2. よく停電するでしょう?

3. よく不平を言うでしょう?

4. よく昼寝するでしょう?

5.よくありがとうって言われるでしょう?

*Repeat this drill with 食べる事はないですね for 食べないですね。 
B．彼、勉強家ですね。

いや、勉強家であるかのごとく、見せているだけですよ。 彼、尊敬していますね。

いや、尊敬しているかのごとく、見せているだけですよ。

1. 彼、楽ですね。

2. 彼、気にしませんね。

3. 彼、思いやりがありますね。

4. 彼, 明るい性格ですね。

5. 彼、仕事が山積していますね。

*Repeat this drill with ように for ごとく.

C、メール、読みましたか。

ええ、でも、読んだきり、何もしていません。

書斎、作りましたか。

ええ、でも、作ったきり、何もしていません。

1. 教科書、買いましたか。

2. 原発に反対しましたか。

3. 協力するって言いましたか。

4. 発展途上国に技術を提供しましたか。

5. 山積する課題について話し合いましたか。

D. あの小説、読んだ? $\quad$ いえ、読みかけて、やめました。 メール、書いた？いえ、書きかけて、やめました。

1. 不平、言った?

2. ケータイ、のぞいた?

3. 名前、聞いた?

4. 避難した?

5. ヨガ、やった?

E．昼寝するのがいいですね。 勤勉な人がいいですね。 ええ、やっぱり昼寝するに限りますね。 ええ、やっぱり勤勉な人に限りますね。

1. 犬を飼うのがいいですね。

2. 思いやりのある人がいいですね。

3. 何度も繰り返すのがいいですね。

4. タバコすわないのがいいですね。

5. だれとでもうまくやるのがいいですね。 
F．大人は、おもしろいと言いますけどねえ。

でも、子どもに言わせると、全然おもしろくないそうですよ。 女性は、つらいと言いますけどねえ。

でも、男性に言わせると、全然つらくないそうですよ。

1. 日本人は、普通だと言いますけどねえ。

2. 空気が読める人は、わかると言いますけどねえ。

3. 先進国の人は、低賃金だと言いますけどねえ。

4. 老人は、地域に帰りたいと言いますけどねえ。

5. 首都圈に住んでいる人は、節電していると言いますけどねえ。

*リスニング練習

Listen to the audio. Indicate whether or not each statement is in line with the main text by marking O (マル: Correct) or X (バツ Incorrect or Undeterminable). Explain in English why you marked an item incorrect or undeterminable.

1.

2.

3.

4.

5.

6.

7.

8.

9. 10.

\section{漢字ドリル}

Listen to the audio for the correct reading of each kanji. Try reading the Kanji yourself during the first pause, listening to the correct reading, and then repeating after the model during the second pause.

1. 吾輩 I/ me / we [nuance of arrogance]

2. 猫年at

3. 飼う to raise / to feed

4. 視点 opinion / point of view

5. 風刺的 satirical

6. 描 $<$ to draw or paint / to depict or describe

7. 夏目漱石 Natsume Souseki

8. 処女 virgin / something original or first

9. 処女小説 original novel / virgin novel / first novel 
10. 発表する to publish / issue / announce

11. 見当 estimate / guess

12. 滅多に thoughtlessly / recklessly

13. 職業 occupation / business

14. 終日 all day / for a whole day

15. 書斎 a study / library

16. 当人 said person / the one concerned

17. 実際 actually / practically

18. 勤勉 industry / diligence

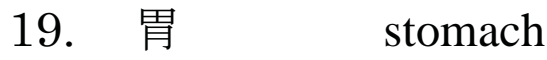

20. 皮膚少

21. 淡黄色 light/pale yellow color

22. 帯びる to carry / to don /to wear [a sword or decoration]

23. 弾力 elasticity / flexibility

24. 活発 vigor / active/ lively

25. 徵候 sign / indication / omen

26. 大飯 big meal / hearty meal

27. 書物 books

28. 繰り返す to repeat / to do something over

29. 日課 daily routine / daily work

30. 勤まる to be fit for / to be equal to

31. 度、来る度 counter for times, every time he/she comes

32. 不平 complaint / dissatisfaction

33. 鳴らす to ring / sound chime 


\section{ぬみなの一言}

A さん

私はどちらかというと、犬より猫の方が好きです。犬は、八方美人 というか、だれにでもしつぽをふるでしょう？その点、猫はゴーイ ングマイウェーですよね。冷めてて、回りを気にしないし、人に媚 びない。見ていると、癒されます。人にも、犬型の人と猫型の人が いると思いません？

B さん 最近ペットブームでペットを飼う人が増えましたねえ。子どもより ペットの方がいいと言うカップルも多いし、子どもがまるで趣味か 何かみたいになりましたね。だから少子化が止まらないのかも。こ れつて、先進国固有の問題じやないですかねえ。

Cさん

ペットは家族の一員です。ちやんと世話できないくせに飼うのは、 無責任です。それから、ペットはおもちゃじやないんだから、リボ ン付けたり、服を着せたり、人形みたいに扱うのは、動物にとつて は、いい迷惑です。ペットの身になってください。みなさん、自己 中な飼い方はやめましょう！ 
Dさん

東日本大震災の後、飼い主を失ったり、別れ別れになったりした犬 が数千匹いたそうです。避難所は犬が禁止だから、連れていきたく ても連れていけないし、ペットも家畜も、被災地にほつたらかしに されて、ビうなつたんでしょうねえ。かわいそうで、かわいそうで、 考えただけで、涙が出ます。

Eさん 地球温暖化などの環境問題は、動物にも影響が出ています。温暖化 の影響を受けやすい北極や南極では、白熊や、クジラ、ペンギンな どの野生動物が激減しています。地球は動物にとつても住みにくい 所になってきたという事です。なんとかしないと、取り返しのつか ない事になりますよ。というか、もうなっちやっているのかもしれ ません。

$$
\text { みんなの一言 表現ノート }
$$

1. 尖装うび美人 everybody's friend, universal flirt

2. 危尾を振る wag a tail/flatter

尻尾を巻く turn tail/ admit defeat

尻尾をつかむ uncover evidence

3. 冷めている cynical, skeptical, not fooled

冷めた見方 cynical viewpoint, cynicism 冷めた見方をする look at things cynically and critically

4. 媚びる flatter, fawn upon, pander 
5. 癒す

7. 少子化

6. まるで

8. いい迷惑

うまくやって行く事は必要だが、人に媚びる必要はない

You need to get along with people, but need not to fawn upon them. 上に媚びる者は下に横柄だ

Those who fawn upon their superiors will domineer over their inferiors.

heal, soothe

癒される be comforted

瘉し菜 a type (of person) who makes you feel relaxed and comforted

almost as if (often with みたい or よう)

まるで猫みたいな人 a person almost like a cat

まるで日本人のようにしゃべる。He speaks almost as if he was a Japanese person.

declining birth rate

高齢化 aging 高齢化社会aging society

しょうしこうれれかか

少子高齢化 decreasing birthrate and aging of population

(good)annoyance

well-intended but inconsiderate and unwanted favor

9. Xの身になる put your self in X's place

お茖様の身になって、サービスを妿考える。

I think about service, putting myself in the customer's shoes.

10. 数干匹

thousands of (animal)

先 Classifier for counting animals

Sound changes (similar to Classifier $\sim$ 本)

ぴき for $1,6,(8), 10$ びき for 3 and 何匹ひ

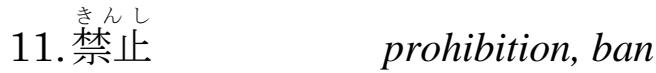

駐車禁止 No Parking 趇ち入り禁止No Trespassing/Keep out

12.ほったらかしにする neglect

ばきげん

13. 激減

sharp decrease

激 $\mathrm{X}$ extreme(ly) $\mathrm{X}$

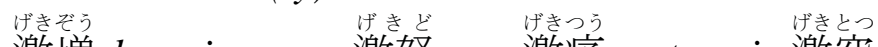

激増 sharp increase 激怒rage 激痛acute pain 激突crash

激辛extremely spicy

14.なんとかしないと unless you do something

15. 㠵取返しのつかない事になる

it will become a fatal blunder, something that cannot be undone 


\section{練習問題}

A. Circle the MOST appropriate item for each blank and translate the entire sentence.

1. エネルギー政策を——ざるを得ない。

2. 防災を——しなければらない。

3. 日本は_—の被曝国だ。

4. 勉強家——かのごとく見せている。

5. ペット禁止だから、アパートで犬は

6. 書斎に きり、終日出てこない。

7. で、がんばれ！

8. 電車では、お年寄りや妊婦に席を

9. 被災 方々に、お見舞い申し上げます

10. は、日本固有のものだ。

11.——に協力してください。

12. 大飯を——度に、よだれをたらす。

13. 教師は、寝ていても勤まる な仕事だ。

14. 滅多に 人も号泣していた。

15. 風刺小説は、漱石 限る。
変わる 変え 変わり 変化し

強化 処理 復旧 課題

世界一唯一最も最大級

です だ な である ない。変え買え 飼え代え 入る 入って 入った 入り 一生懸命 死気 無理 勝手 流そう 譲ろう 解放しよう 運ぼう

するされるされた させた 大戦 米軍 自衛隊 国連 募金 停電 地球温暖化 低賃金 食う食った 食っている 食い 深刻 活発 勤勉 楽 泣く 泣かない 鳴らす 鳴らない がをとと 
B. Based on the written material, answer the questions in English.

人間の勝手な都合で捨てられたり、ほったらかしにされたりするペットが日本だ けでも数万匹いるといわれ、また世界では自然環境の変化の影響で野生動物が激 減している。このように今私たちがなんとかしなければならない問題は山積して いる。

1. Translate the underlined.

2. Give two specific examples of what is referred to.

C. Listen to the audio and translate each response into English.

これ、どんな小説？

1.

2.

3.

4.

5.

6.

D. Writer in Japanese.

Describe your personality from your pet's point of view. If you don't have a pet, make up a fictional pet.

\section{まとめ}

A. Write a satirical or humorous essay about yourself from your pet's point of view.

B. Describe an incident from the viewpoints of the different parties involved. 


\section{参考}

Humor doesn't translate well, especially when it is based on a slip of the tongue. See if you get the humor in the following.

\section{笑い話＼cjkstart腹がよじれる間違い}

http://matome.naver.jp/odai/2129478948138388901 より引用

〉酔っ払って帰宅した夫は、そのまま居間に寝てしまった。

重くてとても寝床まで運べない。

「這（は）って行ってよ」と何度も声をかけたが、

そのたびに夫は「ハッ！ハッ！ハッ！」と答えた。

> 先日、父は、男にフラれて落ち込んでいた姉をなぐさめようとして、

「おまえ、人間は顔じやないぞ」と言うところを、

「おまえの顔は人間じやないぞ」と言ってしまった。

> ある人が就職試験の面接のとき

「家業はなんですか?」と聞かれて

「カキクケコです。」と答えたらしい。

> 某工場内の「おれがやらなきやだれがやる」という看板が、

「だれが」の「が」の点が削られ、

「おれがやらなきやだれかやる」になっていた。この会社の将来は…。

> 新人女子社員の話。電話で「どちらさまですか」と聞きたかったのだろうが 「何様ですか」と聞いていた。

〉 授業が終わって、レポートの提出を先生に聞いてみた。

「先生、今日中ですか?」と言ったら、

「いや、まだ助教授やねん」だって。おいおい。 